\title{
Strengthening the Social Character based on Traditional Children Game Sari Swara at Taman Muda Ibu Pawiyata Elementary School Yogyakarta
}

\author{
Maya Kartika Sari ${ }^{1}$, Suminto A. Sayuti ${ }^{2}$ Pardjono $^{3}$ \\ \{mayakartika84@gmail.com $\left.{ }^{1}\right\}$
}

Universitas PGRI Madiun ${ }^{1}$, Universitas Negeri Yogyakarta, Indonesia ${ }^{23}$

\begin{abstract}
Traditional children game Sari Swara by Ki Hadjar Dewantara is increasingly faded by the current information technology. So, it is necessary to bring up and socialize the children game Sari Swara in the Taman Muda elementary school. It is an effort to strengthen the social character of children. The aim of this study is to analyze the strengthening of social character based on traditional Sari Swara child behavior. It is a qualitative study which used a case study approach. The results showed that the traditional children game Sari Swara by Ki Hadjar Dewantara had been developed and played in Taman Muda elementary school, namely lepetan and jamuran. It could build the social character of the students, such as tolerance, social care, respect, cooperation, responsibility, environment care, creativity, and feeling each other's soul with the group. The children game Sari Swara must always be preserved and developed especially in school.
\end{abstract}

Keyword: Traditional Children Game, Social Character

\section{Introduction}

Education is a tool to develop culture. This statement is stated by Ki Hadjar Dewantara which means the school is a place to maintain and advance the nation's culture [1]. According to Ki Hadjar Dewantara, education and culture have a close relationship with education and arts which are important parts of culture. Art as an educational tool is intended to influence our children's soul towards beauty in its series with nobility and subtlety to be civilized and cultured human [2]. Thus, Ki Hadjar Dewantara formed Taman Siswa school that has culture and art. Top art from education (Amboeka Raras Angesti Wiji) means education will succeed if involving the arts. The learning process in Taman Siswa School always has art and culture. It does not aim to make students as artists but through art and culture it makes virtuous students, love beauty and noble character [3]. Therefore, Ki Hadjar Dewantara creates learning activities through traditional children's methods namely the Sari Swara game, or what is known as the traditional children game Sari Swara. This kind of game covers some conditions of beauty, subtlety, freedom, independence, and national character for students. Sari Swara, by Ki Hadjar Dewantara, is a learning method that combines songs, literatures and stories. these combinations of three aspects can integrate the education of feeling, mind, and culture [3]. Ki Hadjar Dewantara considers that children are independent souls that must be 
developed according to their nature so that a noble character is formed. Children must be introduced to culture, society, and art so that children become highly social souls.

However, the modernization era and technology development of the internet faded students' identity of their culture, especially traditional game. This is because the students tend to play the game using technology, such as play station, mobile phone, and computer. They often play online games and surf the internet to access YouTube, Facebook, and other social media. The technology development can contribute to the negative impact for the students. They tend to play by themselves rather than in groups. It is already known that human need to interact with others since they are social creatures. Therefore, it needs to be concerned for the teacher and parents that the students need to reduce their activity using technology. One of the ways is introducing the attractive traditional children game.

Traditional children's games are the education in packaged games that have important values for children's development. Both motoric and psychological children. Traditional games are far different from modern games that rely on technological progress and practicality. Traditional games utilize simple tools and involve several people to play them. However, it does not reduce the feeling of happiness in playing it games, can be seriously studied as the most important and attractive way of improving the physical, mental, affective, and social health of members of society[4]. Playing traditional games maintains physical health, improves spiritual and mental state, and institutionalizes cultural values. Traditional child care will form an independent spirit of children according to their nature as human beings. Children will be free to express, free to explore, free to collaborate and compete in a healthy manner in the game. According to Ki Hadjar Dewantara taught traditional dolanan through the principle of Wirogo (through the body). wiroso (through feeling), and wiromo (with the rhythm of life or biorhythmic life in character). This is because students love beauty and human nature is happy with beauty so it needs to be facilitated through the appreciation of traditional food [5]. Traditional children's play is a friendly pattern of child education, able to improve performance and foster character, namely fostering mutual respect for friends, good cooperation to achieve victory, fostering a positive social spirit, arousing tolerance between playmates, mutual help between friends, democratic , honest and disciplined in adhering to the rules of the game, creating a sense of environmental care and social care, and fostering a sense of love for the existing culture and preserving traditional games to remain sustainable [6].

Building students' character can be done by doing some activities at school, home, or environment. Fun learning activities, especially game, can be the useful to enhance the students' character. It is because the young students prefer to play rather than study. By playing the game the students can attract the students to learn and develop a way of thinking. It can increase their creativity, imagination, and skills. The research the traditional Javanese children's singing games, dolanan anak, and their function in developing children's cognitive and social skills. Children learn to follow rules and commands; acquire general information about themselves, their family, and their natural environment; and internalize sociocultural values, such as collaboration. The article also highlights the culturally specific musical characteristics of the songs, tembang dolanan anak, for example, the traditional Indonesian gamelan principles, such as tuning systems and the concept of stratified polyphony. In addition, it presents teaching strategies and ideas modified for music teachers to incorporate dolanan anak into their curriculum to meet the national standards and the goal of globalized education [7]. The development of the character of human being plays a strategic role in developing a good conduct. Developing honesty, trust, transparency, and wisdom are important for the human being that they have high dignity. It is expected that good and right character education will result in high civilized and dignity of society [8]. 
Based on these problems appeared, the researchers collaborated with Taman Siswa Ibu Pawiyata Yogyakarta elementary school to maximize the strengthening of the social character which based on the traditional children game of Sari Swara, and to the effectiveness of the traditional children game can influence the students' character.

\section{Research Method}

This is a qualitative study using a case study approach. The aim of the case study is to make the researcher participated directly in her own research to gather the valid data. Besides that, she also wanted to understand deeply about traditional children game Sari Swara by Ki Hadjar Dewantara. The subjects in this study were the Special Arts Agency, principal, teacher, students, and parents. The data collection techniques used was observation, interviews, and documentation. The technique of analyzing the data used the Miles and Huberman models, namely data collection, data reduction, data presentation, and conclusions.

\section{Results and Discussion}

The results indicate that the traditional children game Sari Swara by Ki Hadjar Dewantara had been well developed and implemented in Taman Muda Ibu Pawiyata elementary school Yogyakarta both in learning and in school extracurricular activities. Teachers or tutors provide learning activity through songs so that children feel happy and interested during the lesson.

Ki Priyo Dwiarso, the noble assembly of Taman Siswa Ibu Pawiyata elementary school (transcript of the interview on 2 May 2018), states that Ki Hadjar Dewantara teaches traditional game with the principle of wirogo (body), wiroso (feeling), and wiromo (the rhythm of life or biorhythmic life in character). This is because the students love beauty since human nature likes beauty, so it needs to be facilitated through appreciation of the traditional game. Therefore, the traditional children's game with the Sari Swara method needs to be echoed and popularized to schools, especially in Yogyakarta. According to Ki Priyo Dwiarso, the children game Sari Swara has been replaced by modern games such as gadgets, online games, YouTube, social media and so on, which take up a lot of time for the young generations. It also has an impact on the loss of love for ancestral culture, especially children traditional game. This condition triggers the Taman Siswa foundation and researchers to develop traditional children game, Sari Swara, as an effort to strengthen children's social character.

The Sari Swara method in the Taman Siswa elementary school is implemented in the form of traditional children's game accompanied by Javanese songs and sung together by the teacher and students. The Sari Swara children game which is often played is cublak-cublak suweng, Lepetan, Jamuran, ancak-ancak alis, sluku-sluku bathok, gumregah, Kacang-kacang goreng, and so on. These games basically adhere to freedom of expression, mutual cooperation, and joy. The children also can explore themselves with the surrounding that will develop students' social character and nationality

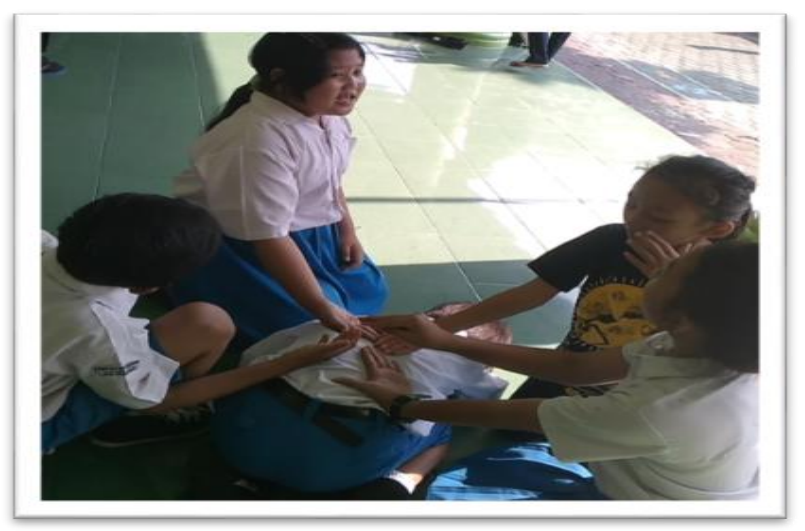


Fig.1.

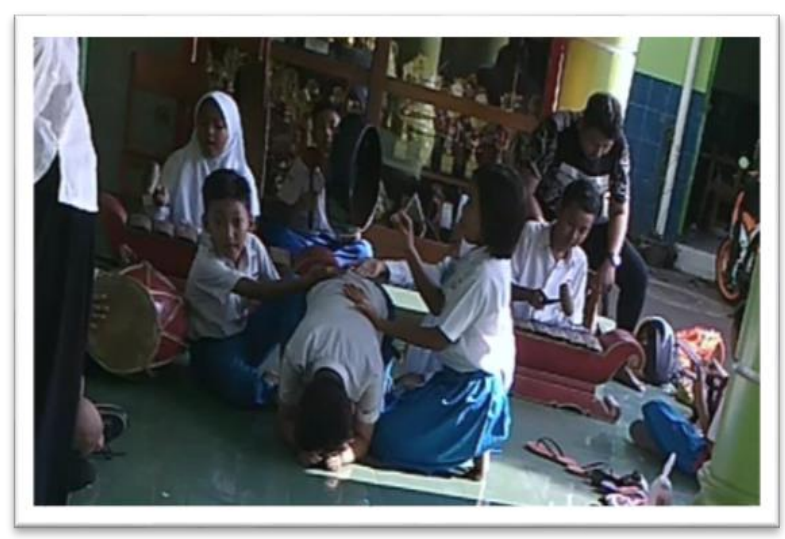

Fig.2.

Dolanan anak cublak-cublak suweng is Ki Hadjar Dewantara's teaching that teaches children to those who prioritize freedom, beauty and honesty. Cublak-cublak Suweng is a game that is carried out by tapping gently on the playing instruments in the form of eardrops as a tool to play. You can replace it with gravel or grains into the palms of the players. dance according to the teachings of Ki Hadjar Dewantara. Cublak-cublak Suweng's dolanan song is as follows :

Cublak-cublak suweng yang artinya : mengetuk-ngetukan subang'

Suwenge ting gelenter yang artinya : subangnya berserakan'

Mambu ketundhung gudel yang artinya : berbau anak kerbau yang terlepas'

Pak empong lera lere yang artinya : kempong bergerak ke sana ke mari'

Sapa ngguyu ndhelikkake yang artinya : siapa yang tertawa dia yang menyembunyikan'

Sir sir pong dhele kopong yang artinya : sir, sir pong kedelai kopong'

Sir sir pong dhele gosong yang artinya : sir, sir pong kedelai kopong'

Dolanan anak cublak-cublak suweng fosters good social values, namely the values of cooperation, responsibility, respect, honesty, religion, responsibility, and social care. Dolanan anak cublak-cublak suweng not only includes motorics butalso including other aspects such as Wirogo (playing game through body activities or motor system), Wiroso (using feeling) and Wiromo (using the rhythm of life or biorhythm of character). 
Other Dolanan anak that is jamuran where children are made in a circle while holding hands and walking around the child in the middle while they are singing the jamuran lyrics

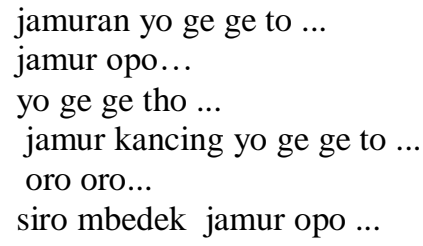

Then the kids crouched down and the child in the middle said it was jamur kethek. After that, the one lining up was looking for a pole to go up and not on the ground. If anyone didn't climb the pole, he will be in the middle. The others lined up in a circle back around the middle and so on. This children game, Jamuran, has an effective social value development where the children are hand in hand which indicates equality. There is no difference between rich and poor students or fat and thin. So, they can tolerate each other and help each other, kinship, love, social care, and environmental awareness. This Jamuran game is effective for developing students' character in the learning process. It can make students become happy with the school; learning becomes fun and conducive and creates good social character.

This game is not the common traditional game which uses the students' motor system but also including other aspects such as Wirogo (playing the game through body activities or motor system), Wiroso (using feeling) and Wiromo (using the rhythm of life or biorhythm of character). This is because the students like arts, so during the game, the students need to use their body to dance, song and gamelan as the musical instrument. Jamuran children game can build the students social characters such as togetherness, cooperation, social care, tolerance, respect, communicative, nationalism, responsibility, creativity, and religiosity.

Besides Jamuran children game, there is some children game which is can be used to develop the students' character. The traditional game of Ancak - ancak Alis is another game which developed in Taman Siswa School. This game also accentuates with Wirogo (playing the game through body activities or motor system), Wiroso (using feeling) and Wiromo (using the rhythm of life or biorhythm of character). This Ancak - ancak Alis game is like the game of snakes and ladders. Nevertheless, this game uses traditional song and gamelan as well as Jamuran game. It can build the value of togetherness and social character among the students. They can understand how to respect others, tolerate of other choice or idea, discipline, be nationalist, and care to their social life.

Children game lepetan is a game in which the students are lined up and crossed hands. Then, the students let go of the other person's hand ties and so on until the final line while singing the song. This game focuses on the three concepts of children game in education; those are Wirogo (playing the game through body activities or motor system), Wiroso (using feeling) and Wiromo (using the rhythm of life or biorhythm of character). This lepetan game can enhance the students' character such as teamwork, cooperation, social care, respect, and nationalism.

The Taman Siswa elementary school teaches the children game of Sari Swara with the intention that the child in his nature as an independent person and likes beauty, the student is optimized the potential according to his talent and interest in learning. Therefore, Taman Muda Ibu Pawiyata elementary school Yogyakarta always teaches children during the lesson and extracurricular activities. The students feel joy and attractive when the teacher presents the traditional game in the class. The children games which are taught at SD Taman Muda Ibu 
Pawiyata Yogyakarta not only involve cognitive, effective, and psychomotor aspects but also foster noble character for the students.

The children game performed at Taman Muda Ibu Pawiyata Elementary School in Yogyakarta, namely lepetan, jaranan,kacang-kacang goreng, ancak ancak alis, cublak-cublak suweng, gumregah, sluku sluku bathok, and jamuran, can build social character of the students. The characters are tolerance, helping others, respect, sportsmanship, cooperation, responsibility, environmental care, creative, and feel each other's soul with the groups. Sari Swara traditional children game must be preserved and developed especially in Taman Siswa schools and schools in Yogyakarta. Therefore, the teachings of Ki Hadjar Dewantara about the essence of Sari Swara children game can build the students to be a better person in the future.

\section{Conclusion}

Taman Muda Ibu Pawiyata elementary school Yogyakarta applies education based on art, namely children 's teachings from the teachings of Ki Hadjar Dewantara, because education must liberate children in a natural way, through children, the free spirit will be conveyed properly as stated in the teachings of Ki Hadjar Dewantara. Child care can foster a social character for children, because children's play arouses the child's independent spirit, trains and sharpens Wirogo (through body), wiroso (through feeling), and wiromo (with the rhythm of life or biorhythmic life in character). Children love beauty because that is necessary to revive the children of Ki Hadjar's teachings in education in Indonesia. The children's play taught by Ki Hadjar Dewantara uses a combination of dolanan songs, dance moves, and gamelan music instruments. This is what makes the children's Dolanan taught by Ki Hadjar Dewantara different from the children's gifts that need to be preserved and developed in schools outside Taman Siswa.

\section{Recommendation}

The Taman Siswa School needs to include children's school as a special curriculum in Taman Siswa and develop children's lessons taught by Ki Hadjar Dewantara to other schools through various events such as children's festivals, art shows and children's shows, children's games, etc. which can evoke the spirit of schools in Yogyakarta to get to know and popularize the children's Dolanan taught by Ki Hadjar Dewantara

\section{Reference}

[1] Majelis Luhur Persatuan Tamansiswa, "Ki Hadjar Dewantara; pemikiran, konsepsi, keteladanan dan sikap merdeka bagian 1. Pendidikan. Cetakan ke-5," Cetakan ke., Yogyakarta: UST Press bekerjasama dengan Majelis Luhur Persatuan Tamansiswa, 2013, p. 264.

[2] Majelis Luhur Persatuan Tamansiswa, Ki Hadjar Dewantara; pemikiran, konsepsi, keteladanan dan sikap merdeka bagian 1. Pendidikan. Cetakan ke-5. Yogyakarta: UST Press bekerjasama dengan Majelis Luhur Persatuan Tamansiswa, 2013. 
[3] M. L. P. Tamansiswa, Ki Hadjar Dewantara; pemikiran, konsepsi, keteladanan dan sikap merdeka bagian 1. Pendidikan. Cetakan ke-5. Yogyakarta: UST Press bekerjasama dengan Majelis Luhur Persatuan Tamansiswa, 2013.

[4] K. Pebryawan, "ENGKLEK SEBAgAi SARANA PEMBELAJARAN YANG ASIK DI TENGAH PERMAINAN MODERN DI TENGAH PERMAINAN MODERN,” no. 92, pp. 62-68, 2015.

[5] M. R. Dehkordi, "The Educational Impact of Traditional Games : the Role of Zurkhaneh Sport in Educating Children," vol. 5, no. September, pp. 134-139, 2017.

[6] M. K. Sari, "PATTERNS OF CHILD FRIENDLY EDUCATION THROUGH THE AMONG SYSTEM AND TRADITIONAL GAME TEACHINGS OF KI HADJAR DEWANTARA,” in Proceeding of International Conference On Child-Friendly Education, 2018, pp. 201-205.

[7] J.-C. Wang, "Games Unplugged! Dolanan Anak, Traditional Javanese Children's Singing Games in the 21stCentury General Music Classroom,” Gen. Music Today, vol. 28, no. 2, pp. 5-12, 2015.

[8] U. Mulyono, "Pendidikan Nilai Luhur Melalui Tembang (Lagu) Dolanan Anak," SELONDING, vol. 1, no. 1, pp. 100-112, 2013. 